\title{
A Web-based Learning System using Project-based Learning and Imagineering
}

\author{
https://doi.org/10.3991/ijet.v12i05.6344 \\ Pinanta Chatwattana \\ King Mongkut's University of Technology North Bangkok, Bangkok, Thailand \\ pinanta.c@cit.kmutnb.ac.th \\ Prachyanun Nilsook \\ King Mongkut's University of Technology North Bangkok, Bangkok, Thailand \\ prachyanun@hotmail.com
}

\begin{abstract}
A web-based learning system using project-based learning and Imagineering relies on the online operation, which can be operated on all kinds of computers and mobile devices. The objectives of the development of this web-based learning system are to encourage the freedom of self-learning, to promote interaction and cooperation based on the concepts and theories of project-based learning and Imagineering learning, and to create instructional activities based on the new concepts corresponding to characteristic development of learners in the 21 st century, which enables the learners to have creativity and ability to generate new innovation. Regarding the architecture design, the researcher employed the concepts of mixed learning process, which is the combination of project-based learning and Imagineering learning, in order to support the instructional process within the system. Also, the researcher relied on the flexible instructional activities and instructional management system so that the learners could acquire the efficient learning from the system. Moreover, there was a variety of communication devices to support and promote the collaboration and activities within the system. The results of this research can be summarized as follow: (1) The system architecture consists of three main elements, i.e. 1.1) Stakeholders; 1.2) System Components, i.e. Learning process, Activity, System Element, and Communication Tools; and 1.3) Database; (2) Learning process within the system consists of six steps, corresponding to the Imagineering learning, i.e. 1) Imagine 2) Design 3) Develop 4) Present 5) Improvement and 6) Evaluate; and (3) The web-based learning system, can be divided into two systems: 1) Student system; and 2) Lecturer system and administrator system.
\end{abstract}

Keywords-Web-based Learning System, Project-based Learning, Imagineering 


\section{Introduction}

Child-centered learning is one of several many learning management systems that encourage students to learn and solve problems independently [1]. It also encourages students to use information technology to benefit their learning process. Thus, webbased learning, is another form of technology that can support independent learning. Furthermore, these technologies are also adopted side by side with classroom management. In order to efficiently manage web-based learning, teachers need to consider the process and method that is consistent and suitable for teaching specific subjects.

\subsection{Project-based learning}

Project-based learning is a method of learning that provides opportunities for students to study, research and practice by themselves, and according to their abilities, aptitudes and interests by using scientific processes, or any other possible processes, that can be used to find answers to questions, while teachers closely provide guidance and advice. A project can be done at any educational level, and may be done individually or as a group, depending on the complicatedness of the project. A group project allows students to help each other, think how to solve problems and how to implement solutions. Therefore, every student can participate in the solution making and problem solving process [2].

\subsection{Imagineering learning}

Imagineering learning is a novel concept in which the learning management is created in line with the characteristics of 21 st century learners. It emphasizes the process of self-learning, creativity and the ability to create innovations. A tangible target task prompts learners to begin their projects from their initial ideas to implementing the process at every step, from the format of the informational task, the media and technology in use, the process of choosing, to the management and use of the task to communicate to others in a comprehensible manner [3]. Nilsook and others [4] mentioned and summarized the six aspects of Imagineering learning as (1) Imagination; the ability to come up with topics of interest using brain-storming and imagination, which results in a topic that all group members are interested in; (2) Design, the ability to research from documents or experts, including the implementation of planning and designing the task by sketching or drawing a storyboard, for example, to achieve the prototype model; (3) Developing, the ability to work step by step; (4) Presentation, the ability to prove the group's work empirically to the public by presentation method; (5) Improvement, the ability to improve or adjust and summarize work done together; and (6) Evaluation, the ability to evaluate work quality, considering one's own output and the group's output, and whether the finished work is satisfying. All six aspects focus on the self-learning process by actualizing students' imagination into practical and objective inventions or innovations. 


\subsection{Cooperative learning}

Cooperative learning is a kind of instructional management that encourages the learners to use their own competence and skills to solve the problems of the team; thereby, all of the group members shall realize their participation in the team. The success of cooperative learning is dependent on various skills, such as social skill, interactive skill, teamwork skill, communication skill, problem-solving skill, etc., and it requires respect, acceptance, and mutual confidence. The instructors should teach and train the learners about the aforementioned issues in order to facilitate the cooperative learning. There are five main elements of cooperative learning including (1) Positive Interdependence, (2) Face to Face Promotion Interaction, (3) Individual Accountability, (4) Interpersonal and Small Group Skills, and (5) Group Processing $[5][6]$.

The aforementioned principles and theories have led to the development of the web-based learning system using project-based learning and Imagineering. This further enhances the creative construction of multimedia skills and cooperative learning skills, and is used as a tool to promote learning, interaction and cooperative while working, in order to enhance the creative construction of multimedia skills and cooperative learning skills.

\section{Research Objective}

1. To analyzed and synthesized the conceptual framework for the web-based learning system using project-based learning and Imagineering.

2. To design the use case diagram, system architecture and system structure for the web-based learning system using project-based learning and Imagineering.

3. To develop a web-based learning system using project-based learning and Imagineering.

4. To evaluate the quality and efficiency of the web-based learning system using project-based learning and Imagineering.

5. To evaluate the suitability on the design of instructional activities and practical use of the web-based learning system using project-based learning and Imagineering.

\section{Scope of Study}

1. The samples were five experts, purposively sampled from an educational institute with expertise in computer, information and communication technology for education, and educational technology.

2. The tools used in this research were a developed web-based learning system a quality and efficiency evaluation form developed with a five level rating scale. 


\section{$4 \quad$ Methodology}

A web-based learning system using project-based learning and Imagineering, is a research and development programme that consists of five phases, which are in line with the ADDIE model of instructional design [7], and is widely used and accepted for instruction and learning design.

\subsection{Phase 1: Analyse andaaaaaa synthesize the conceptual framework from the literature review and researches.}

The researcher studied, analyzed, and synthesized the relevant documents and researches by integrating different theories in order to create the conceptual framework of web-based learning that could be applied to develop the desirable learning skills of learners, as shown in figure 1 . The synthesis of the conceptual framework of a webbased learning consisted of two elements, i.e. literature review and researches. The synthesized conceptual framework was designed based on the integration of the following theories: Instruction System, Web-based Instruction, Project-based Learning (PjBL), Imagineering Learning, Cooperative Learning.

Web-based Learning System using Project-based Learning and Imagineering : According to the integration of the relevant theories and researches, the conceptual frameworks of the web-based learning system using project-based learning and Imagineering included: (1) Stakeholders, i.e. students, lecturers, and system administrators; (2) System Components, i.e. Learning Management System (LMS), Content Management System (CMS), Test Management System (TMS), and a Delivery Management System (DMS); and (3) Database.

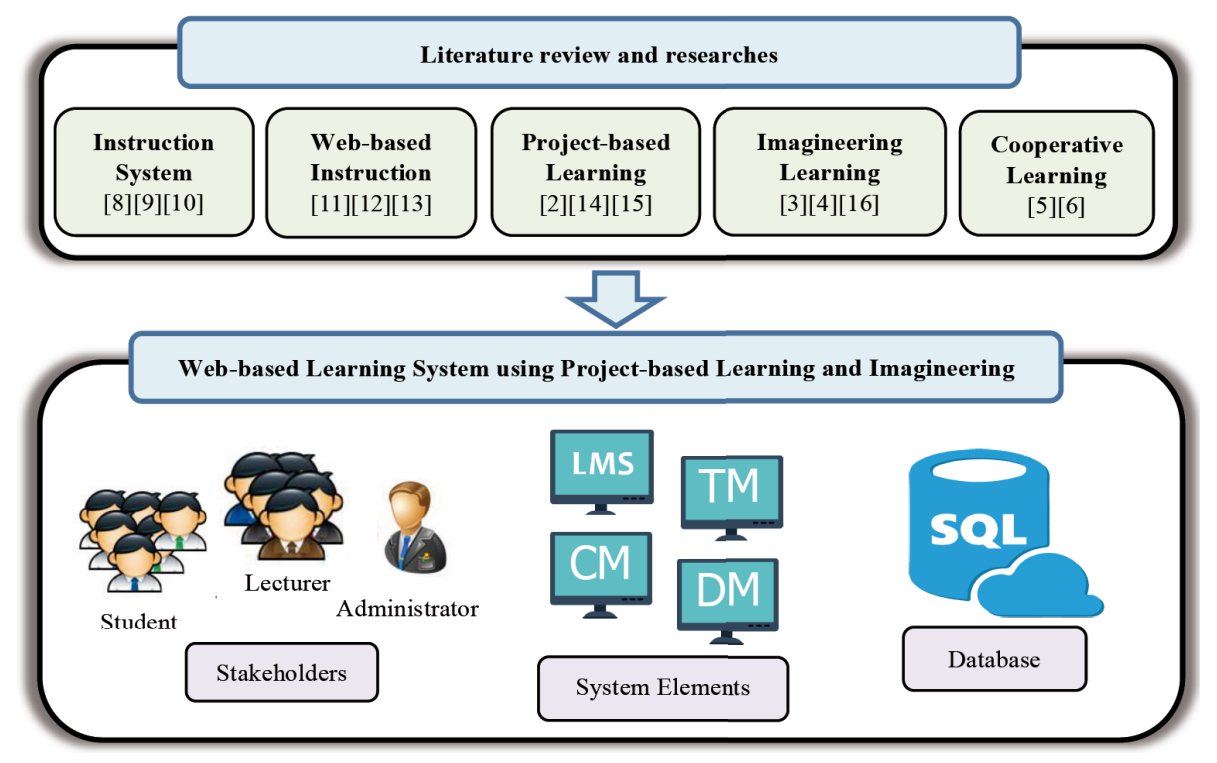

Fig. 1. Conceptual Framework 


\subsection{Phase 2: Design a web-based learning system using project-based learning and Imagineering.}

The design of the developed web-based learning system consisted of (1) the use case diagram; (2) the system architecture of the web-based learning system; (3) the system structure of the web-based learning system; (4) the system element of the webbased learning system; (5) an entity-relationship diagram (ER Diagram) used for designing the database; and (6) a user interface.

A. Use case diagram: Use case diagram is a tool to design the overall picture of system. It illustrates the relationship between stakeholders/ users and the sub-systems. The use case diagram is shown in figure 2.

Administrator is responsible for setting user permission, setting courses, setting primary instructors, and setting user groups.

Student is responsible for studying the lesson contents, doing online tests, doing instructional activities, and working on the assigned projects.

Lecturer is responsible for the management of learning system, e.g. modifying the lessons (add/edit the contents, add/edit the documents, add/edit the work sheets), managing the learners (add/delete/edit the learners, add/edit the project scores and the behavior of learners), managing the tests (add/edit/delete the tests), etc.

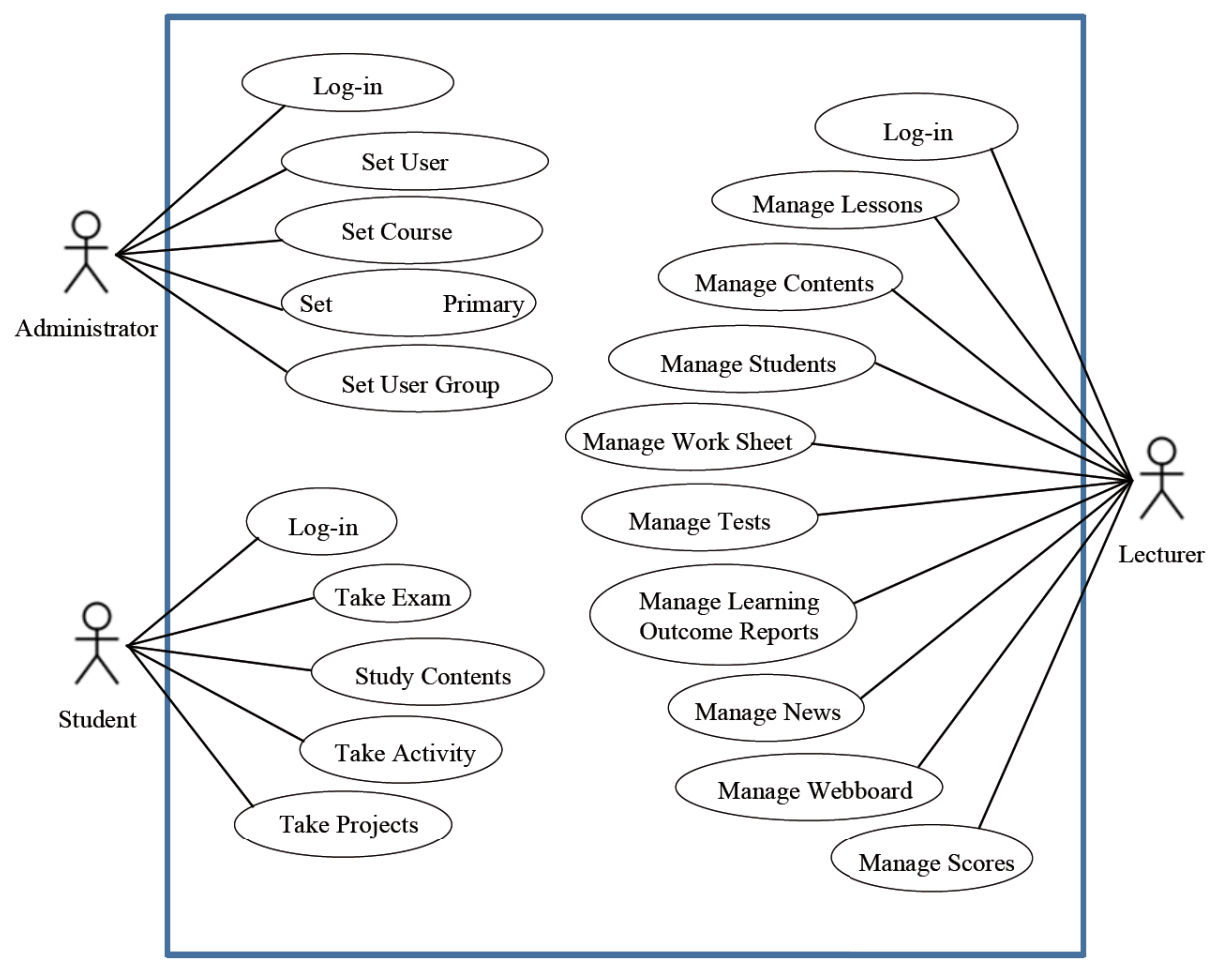

Fig. 2. Use case diagram 
B. System Architecture: The system architecture of the web-based learning system using project-based learning and Imagineering in figure 3 represents the elements and operation structure within the system that promote the creative construction of multimedia skills and cooperative learning skills. The developed architecture of a web-based learning system consists of three major elements as below.

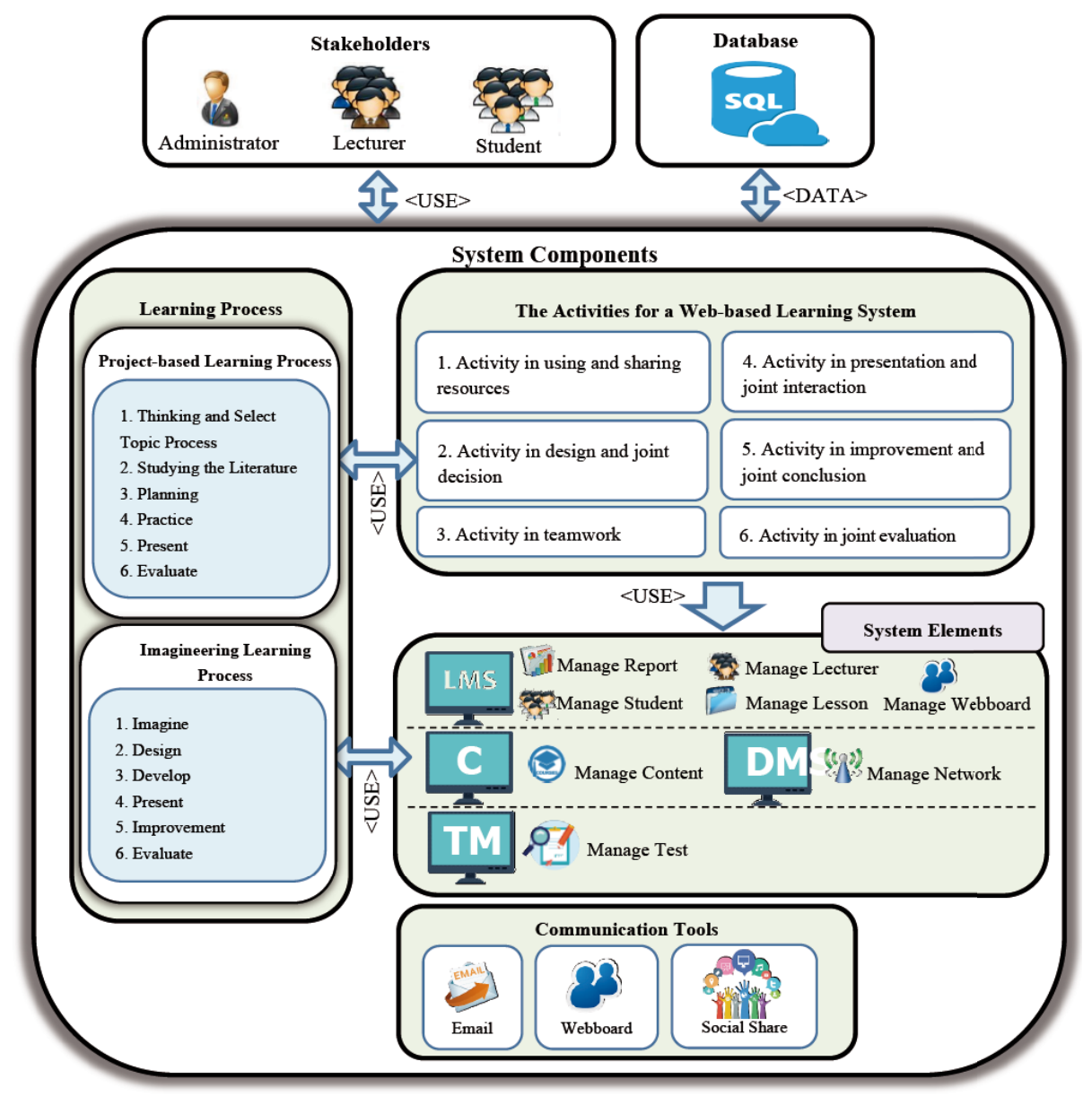

Fig. 3. System Architecture

1. Stakeholders : Stakeholders/persons involved refer to those associated with the use of a web-based learning system, i.e. administrator, lecturer, and student. To use the system, the administrator, the lecturer, and the student must first log in to the system, and then either of them can work on their own default tasks in the next step. The responsibilities of the administrator are to set user permission, set course, set primary instructor, and set user groups. 
2. System Components : The architectural components of the web-based learning system using project-based learning and Imagineering include the following four components.

- Learning Process : The web-based learning system using project-based learning of Imagineering is primarily based on the integration of two important theories, i.e. Project-based Learning (PjBL) and Imagineering Learning, in order to create the learning process that can promote the creative construction of multimedia skills and cooperative learning skills. The details of either theory can be described as follow.

Project-based Learning ( $\mathrm{PjBL}$ ) is the learning method that enables the learners to have participation in the operation, working either by themselves or in group, based on their competence, skills, and interest. The operation relies on the creative thinking process so as to find out the particular solutions. It is also assisted by the instructors' suggestions and advice. The project-based Learning (PjBL) is composed of six steps, i.e. 1) Think and select topics, 2) Study the literature, 3) Plan, 4) Practice, 5) Present, and 6) Evaluate.

Imagineering Learning is a new concept of instructional management focusing on the characteristic development of learners in the 21 st century, which enables the learners to learn by themselves, to have creativity and ability to generate new innovation. Imagineering Learning consists of six steps, i.e. 1) Imagine, 2) Design, 3) Develop, 4) Present, 5) Improvement, and 6) Evaluate.

- $\quad$ Activity for a Web-based Learning System Learning Process : The instructional activities using project-based learning and Imagineering consist of six activities that are in compliance with the six aspects of Imagineering learning process. The elements of cooperative learning used to enhance the creative construction of multimedia skills and cooperative learning skills include: 1) Activity in using and sharing resources, 2) Activity in design and joint decision, 3) Activity in teamwork, 4)Activity in presentation and joint interaction, 5)Activity in improvement and joint conclusion, and 6) Activity in joint evaluation.

The characteristics for six activities of the web-based learning system using project-based learning and Imagineering learning process as shown in table 1 .

In the table 2 is the summary of synthesis on the behaviors that were measured by the six instructional activities on the web-based learning system to see the creative construction of multimedia skills and cooperative learning skills. The synthesis was conducted in a way that corresponded to the six aspects of Imagineering process and the to the elements of cooperative learning. 
Table 1. Characteristics for six activities of the web-based learning system using Imagineering learning process

\begin{tabular}{|c|c|c|}
\hline Imagineering Process & Activity & Characteristics \\
\hline Imagine & $\begin{array}{l}\text { Activity in using and } \\
\text { sharing resources }\end{array}$ & $\begin{array}{l}\text { Ability to find out the most interesting topic of project by } \\
\text { means of brainstorming and imagination. }\end{array}$ \\
\hline Design & $\begin{array}{l}\text { Activity in design } \\
\text { and joint decision }\end{array}$ & $\begin{array}{l}\text { Ability to search for the data from literatures or the experienced } \\
\text { ones, and then plan and design the project by drafting or making } \\
\text { a story board, etc., in order to derive the project model. }\end{array}$ \\
\hline Develop & $\begin{array}{l}\text { Activity in team- } \\
\text { work }\end{array}$ & $\begin{array}{l}\text { Ability to take step-by-step action corresponding to the funda- } \\
\text { mental design, with obvious division of work in order to } \\
\text { achieve the expected outcome. }\end{array}$ \\
\hline Present & $\begin{array}{l}\text { Activity in presenta- } \\
\text { tion and joint inter- } \\
\text { action }\end{array}$ & $\begin{array}{l}\text { Ability to prove the project before the public by means of } \\
\text { presentation. }\end{array}$ \\
\hline Improvement & $\begin{array}{l}\text { Activity in im- } \\
\text { provement and joint } \\
\text { conclusion }\end{array}$ & Ability to improve and and joint conclusion. \\
\hline Evaluate & $\begin{array}{l}\text { Activity in joint } \\
\text { evaluation }\end{array}$ & $\begin{array}{l}\text { Ability to evaluate of work the results by considering the outcome } \\
\text { of individual and of the group to see whether the quality is } \\
\text { satisfactory or not. }\end{array}$ \\
\hline
\end{tabular}

Table 2. Behaviors to be measured for six activities of Imagineering learning process

\begin{tabular}{|c|c|c|c|}
\hline $\begin{array}{l}\text { Imagineering } \\
\text { Process }\end{array}$ & Instructional Activity & $\begin{array}{c}\text { Behaviors to be measured in order } \\
\text { to enhance the creative construc- } \\
\text { tion of multimedia skills }\end{array}$ & $\begin{array}{l}\text { Behaviors to be measured } \\
\text { in order to enhance the } \\
\text { cooperative learning skills }\end{array}$ \\
\hline Imagine & $\begin{array}{l}\text { Activity in using and } \\
\text { sharing resources }\end{array}$ & $\begin{array}{l}\text { 1.Definition of imagination issues in } \\
\text { the project } \\
\text { 2.Summary of project topics }\end{array}$ & $\begin{array}{l}\text { 1.Searching and storing infor- } \\
\text { mation } \\
\text { 2.Sharing of information } \\
\text { 3.Joint synthesis of infor- } \\
\text { mation }\end{array}$ \\
\hline Design & $\begin{array}{l}\text { Activity in design and } \\
\text { joint decision }\end{array}$ & $\begin{array}{l}\text { 1.Step-by-step design process } \\
\text { 2.Achievement in design of project } \\
\text { model }\end{array}$ & $\begin{array}{l}\text { 1.Participation in work } \\
\text { 2. Working with others }\end{array}$ \\
\hline Develop & Activity in teamwork & $\begin{array}{l}\text { 1.Step-by-step development of the } \\
\text { project } \\
\text { 2.Achievement of the project }\end{array}$ & $\begin{array}{l}\text { 1.Attention to the project } \\
\text { 2.Attention to the monitor- } \\
\text { ing of group-project } \\
\text { 3.Quality of the project }\end{array}$ \\
\hline Present & $\begin{array}{l}\text { Activity in presenta- } \\
\text { tion and joint interac- } \\
\text { tion }\end{array}$ & $\begin{array}{l}\text { 1.Step-by-step presentation of the } \\
\text { project } \\
\text { 2.Achievement in communication }\end{array}$ & $\begin{array}{l}\text { 1. Responsibility in the presen- } \\
\text { tation of the project }\end{array}$ \\
\hline Improvement & $\begin{array}{l}\text { Activity in improve- } \\
\text { ment and joint conclu- } \\
\text { sion }\end{array}$ & $\begin{array}{l}\text { 1.Step-by-step correction of the } \\
\text { project } \\
\text { 2.Achievement of the corrected project }\end{array}$ & $\begin{array}{l}\text { 1.Enthusiasm in problem- } \\
\text { solving } \\
\text { 2.Responsibility in joint } \\
\text { conclusion }\end{array}$ \\
\hline Evaluate & $\begin{array}{l}\text { Activity in joint evalu- } \\
\text { ation }\end{array}$ & 1.Reasonable discussion and opinions & $\begin{array}{l}\text { 1.Attitudes toward the work } \\
\text { 2.Discussion and interaction } \\
\text { with the group }\end{array}$ \\
\hline
\end{tabular}


- $\quad$ System Elements : System Elements are the features that administrators, lecturers, and students use for instructional management within the web-based learning system. The system elements include the following four major parts.

1. Learning Management System (LMS) is the system that lecturers and students use to manage report, lessons, students, webboard, etc.

2. Content Management System (CMS) is used to manage and present contents as well as other document files.

3. Test Management System (TMS) is used to evaluate the students' achievement based on the learning process. Thus, the function of TMS is primarily to support the test management.

4. Delivery Management System (DMS) delivers the lessons to the students to learn them through computer network such as internet, intranet, and via other different channels.

- Communication Tools : Communication tools are used to support and encourage the students to learn and work collaboratively within the web-based learning system by means of two-way communication. This is to promote the interaction between students and students, or students and lecturers, etc. There are several kinds of communication tools such as email, webboard, social share on internet.

1. Email : The students can submit their assignments/exercises or inquire about the instructional information via emails on their mobile devices or computers.

2. Webboard : Webboard is a two-way communication tool by which the students can directly contact other students or their lecturers and then receive the feedback immediately.

3. Social Share : Social Share is a communication tool on network system that allows the students to exchange contents, send messages, and communicate via social media, e.g. facebook, Twitter, Google Doc, etc.

3. Database : Database stores the information of students, lecturers, and administrators. The researcher decided to use MySQL program to manage the database system, which included test scores, tests, history, access to the system, subjects, contents, etc.

C. System Structure : The system structure of the web-based learning system is shown in figure 4 . The web-based learning system, can be divided into two systems: (1) Student system; and (2) Lecturer system and administrator system.

D. System Elements : The system elements of the web-based learning system is shown in figure 5. System elements are the features that administrators, lecturers, and students use for instructional management within the web-based learning system. The system elements consists of four major parts, i.e. Learning Management System (LMS), Content Management System (CMS), Test Management System (TMS), and Delivery Management System (DMS). 


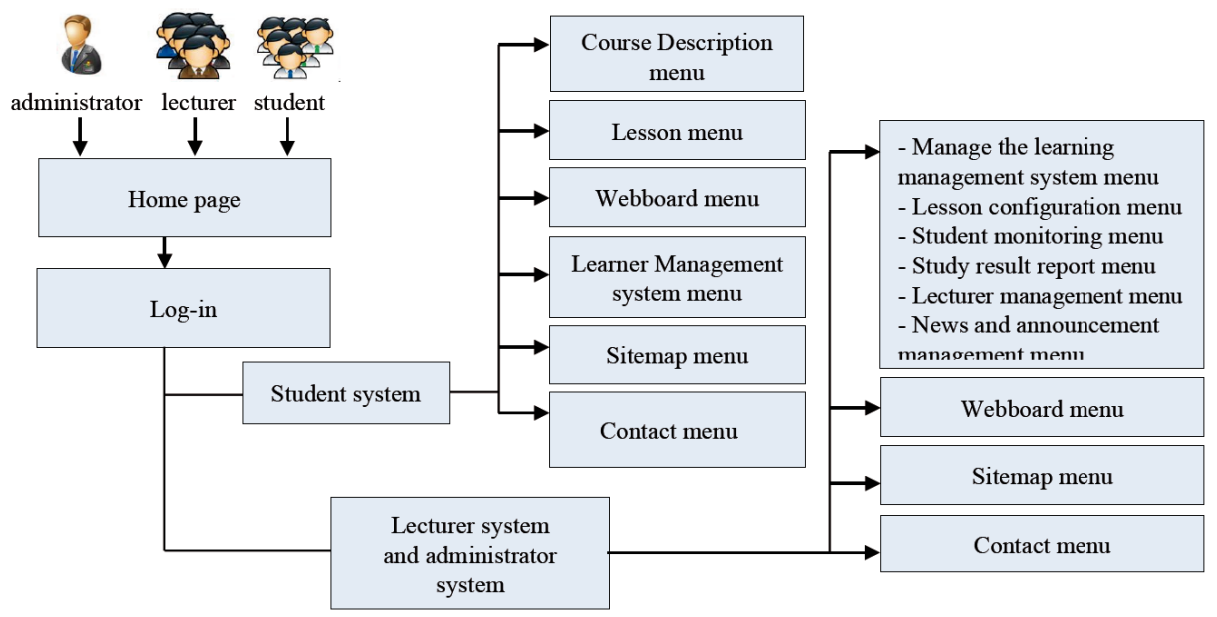

Fig. 4. System Structure

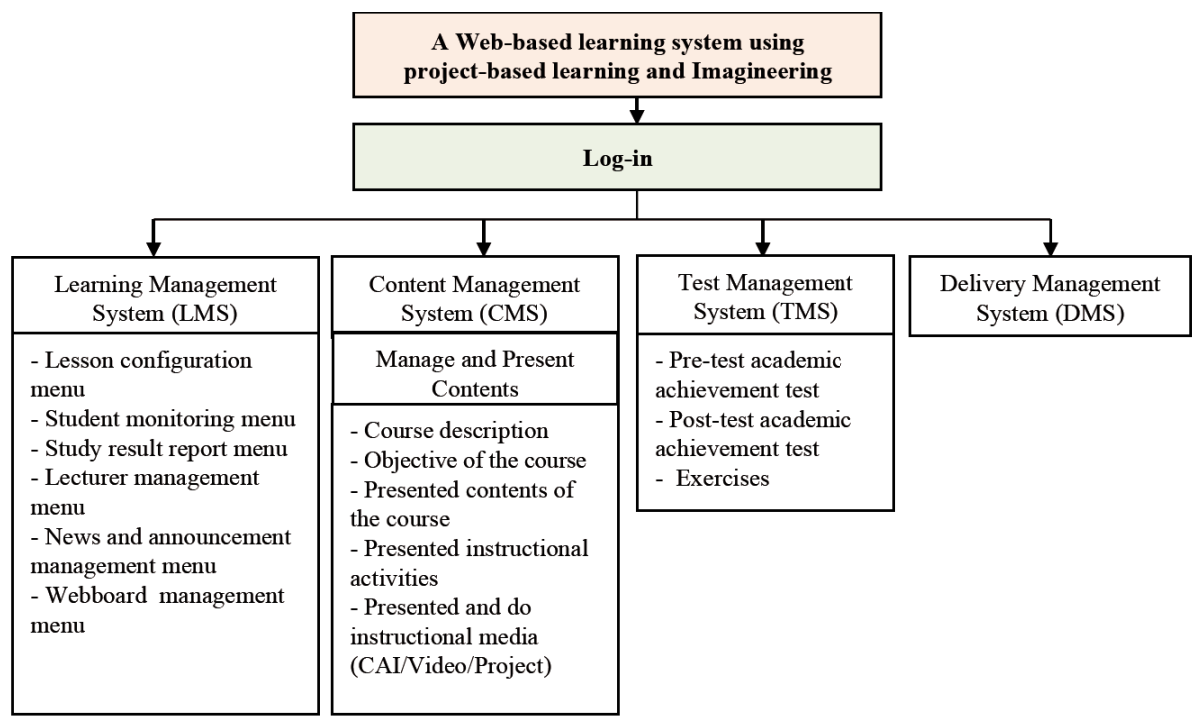

Fig. 5. System Elements

\subsection{Phase 3: Developing a web-based learning system using project-based learning and Imagineering.}

The researchers developed the web-based learning system using PHP language and built the database with a MySQL program. 


\subsection{Phase 4: Testing a web-based learning system using project-based learning and Imagineering.}

Researchers employed the Blackbox testing technique [17] which consisted of four steps as follows: (1) unit testing; (2) module integration testing; (3) system testing; and (4) acceptance testing to verify the validity, errors and completeness of the developed system. This method was implemented by the researchers.

\subsection{Phase 5: Evaluating a web-based learning system using project-based learning and Imagineering.}

An evaluation was made to assess the quality and efficiency of the developed webbased learning. The evaluation was done by five experts from a renowned educational institute with expertise in computer, information and communication technology for education, and educational technology. The evaluation was done via an evaluation form developed by the researchers.

\section{$5 \quad$ Results}

A web-based learning system using project-based learning and Imagineering can be applied to all subjects that were taught by means of project-based technique. This web-based learning system was tested in the subject of Multimedia Technology And Animation, and the summary results thereof were divided into three sections as follow.

\subsection{Section 1: Result of the development of the web-based learning system using project-based learning and Imagineering.}

The web-based learning system, can be divided into two systems: (1) Student system; and (2) Lecturer system and administrator system. The home page of the webbased learning system is operated online as shown in figure 6 .

(A) Student system : this part shows course descriptions, multimedia lesson content, and the student management system, including a webboard. The student system consisted of six menus were as follows:

The student system consisted of six menus as follows:

1. The course description menu presented descriptions, details and the expected objective of the course used in the developed web-based learning system.

2. The lesson menu presented contents of the course. The presentation was a linear pattern. The process and steps were: 1) students completed pre-test academic achievement test; 2) students studied the entire eight chapters of the course and do activities assigned by lecturer to enhance the creative construction of multimedia skills and cooperative learning skills. The activity of the web-based learning system using project-based learning and Imagineering to enhance the creative con- 
struction of multimedia skills and cooperative learning skills was divided into six activities; and 3 ) students completed a post-test academic achievement test.

3. A webboard menu is another tool used to enhance students' learning processes. This allows students to do activities assigned by lecturer to enhance the creative construction of multimedia skills and cooperative learning skills.

4. The student management menu consisted of tools that enhance learning for students, such as: personal information editing menu; class attendance record menu; study result menu; check project score menu; check assignment score menu; digital assignment submission menu; teaching documents download menu; and assignment download menu.

5. Sitemap menu presented all of the available menus in the student system.

6. Contact menu presented details of the responsible lecturers in the course.

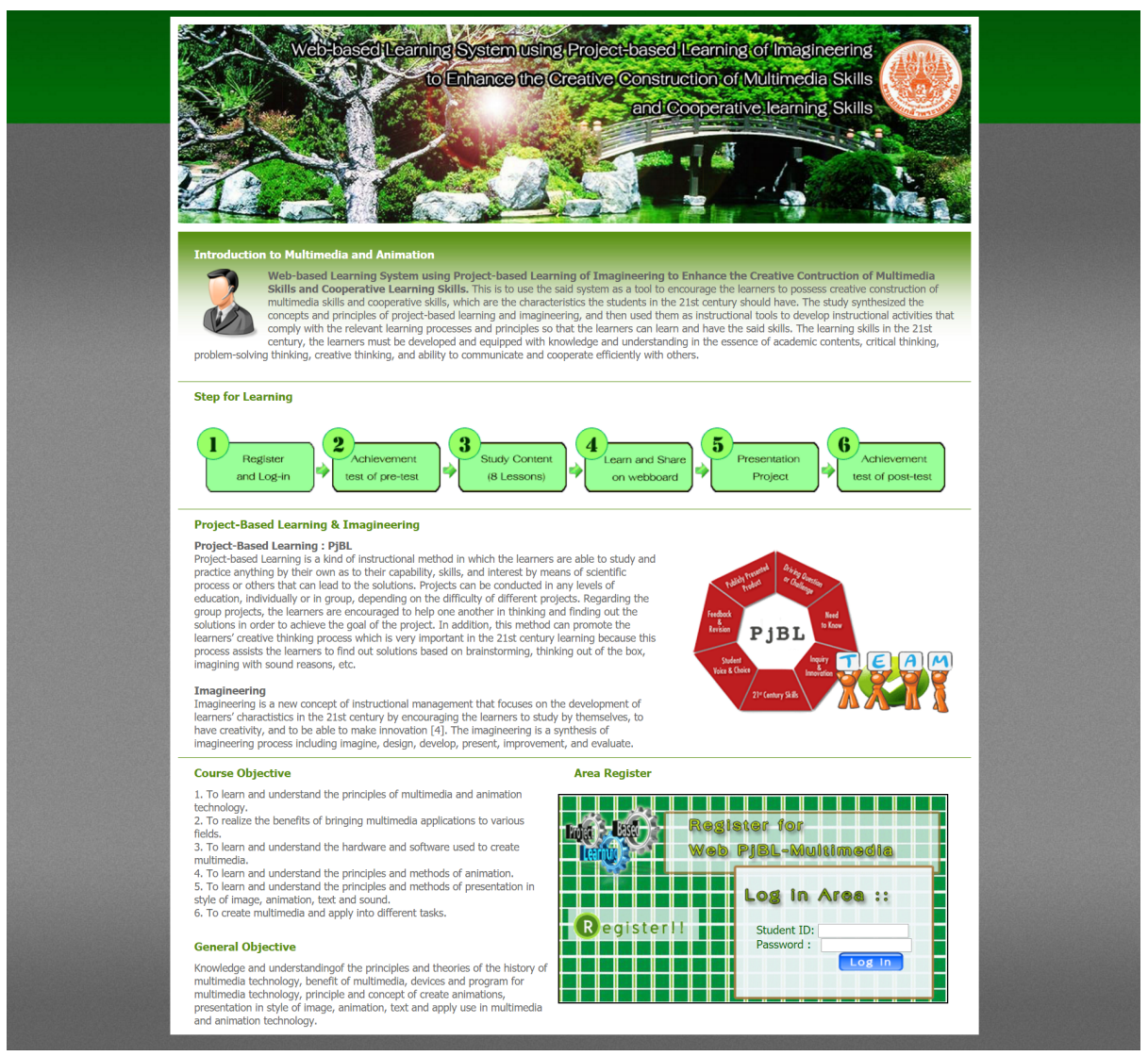

Fig. 6. Home page of the web-based learning system

(B) Lecturer system and administrator system : this part shows an administrative and learning management system made for the students. There were seven menus in the lecturer system and administrator system. 
1. Lesson configuration menu consisted of teaching document management menu (edit/show teaching document), work sheet management menu (edit/show work sheet), test management menu (add/edit/delete/show tests).

2. Student monitoring menu consisted of student list menu, student management (add/delete/show students list), homework/practice scoring menu, study result menu, project assignment management/student behavior, and end-of-chapter practice scoring management menu.

3. Learning outcome report menu consisted of attendance statistics menu, test score statistics menu, project assignment score statistics, and end-of-chapter practice score statistics menu.

4. Lecturer management menu consisted of an adding lecturer menu, lecturer information menu, lecturer information update menu, and show all lecturers menu.

5. News and announcement management menu consisted of adding news and announcement menu, editing and news and announcement menu, show announcements menu.

6. Webboard menu: lecturer can add/delete and answer threads posted by students.

7. Sitemap menu presented all of the available menus in the Lecturer system or administrator system.

\subsection{Section 2: Results of the quality and efficiency evaluation of the web-based learning system, using project-based learning and Imagineering.}

An evaluation of the quality and efficiency of the developed web-based learning was made by five experts from a renowned educational institute with expertise in computer, information and communication technology for education, and educational technology. The results are described in the following paragraphs.

1. The results of an evaluation of the contents and quality of the design of the web-based learning system were made under six evaluation frameworks: contents, learning activities, graphic and language, fonts and colors, tests, and web-based learning system design, as summarized in Table 3.

Table 3. Results of the quality evaluation under 6 evaluation frameworks

\begin{tabular}{|c|c|c|c|}
\hline \multirow{2}{*}{ Evaluated contents } & \multicolumn{2}{|c|}{ Evaluation outcome } & \multirow{2}{*}{ Quality level } \\
\hline & $\overline{\mathrm{x}}$ & S.D. & \\
\hline 1. Contents & 4.74 & 0.44 & highest \\
\hline 2. Learning activities & 4.04 & 0.35 & high \\
\hline 3. Graphic and language & 4.72 & 0.46 & highest \\
\hline 4. Fonts and colors & 4.48 & 0.51 & high \\
\hline 5. Tests & 4.40 & 0.50 & high \\
\hline 6. Web-based learning system design & 4.38 & 0.60 & high \\
\hline Overall system quality & 4.49 & 0.54 & high \\
\hline
\end{tabular}

Table 3 shows that the overall evaluation for the design and quality of the contents of the web-based learning system was rated as high $(x=4.49$, S.D. $=0.54)$. When considering each aspect, it was found that the content quality had the highest rating of all 
$(x=4.74$, S.D. $=0.44)$, followed by graphic and language, which also rated at the highest quality level $(\underline{x}=4.72$, S.D. $=0.46)$, and fonts and colors, which was rated at a high quality level $(\overline{\mathrm{x}}=4.72$, S.D. $=0.46)$.

2. Result of the efficiency evaluation of the developed web-based learning system under five evaluation frameworks: system competency, functionality, usability, security and performance, as summarized in Table 4.

Table 4. Results of the system efficiency evaluation under 5 evaluation framework

\begin{tabular}{|l|c|c|l|}
\hline \multirow{2}{*}{\multicolumn{1}{|c|}{ Evaluated contents }} & \multicolumn{2}{c|}{ Evaluation outcome } & \multirow{2}{*}{ Efficiency level } \\
\cline { 2 - 3 } & $\overline{\mathrm{x}}$ & S.D. & \\
\hline 1. System competency & 55.4 & 55.0 & highest \\
\hline 2. Functionality & 84.4 & 37.0 & highest \\
\hline 3. Usability & 60.4 & 50.0 & highest \\
\hline 4. Security & 57.4 & 63.0 & highest \\
\hline 5. Performance & 00.4 & 76.0 & high \\
\hline & $\mathbf{4 . 5 5}$ & $\mathbf{0 . 5 8}$ & highest \\
\hline
\end{tabular}

Table 4 shows the efficiency evaluation of the web-based learning system under five evaluation frameworks. Overall efficiency was rated at the highest level $(\bar{x}=4.55$, S.D. $=0.58)$. When considered separately, it was found that the efficiency evaluation of functionality was rated at the highest level $(\bar{x}=4.84$, S.D. $=0.37)$, followed with usability, security, system competency and performance, respectively.

5.3 Section 3: Results of the suitability evaluation on the design of instructional activities and practical use of the web-based learning system using Imagineering learning process.

An evaluation of the suitability evaluation on the design of instructional activities and practical use of the web-based learning system using Imagineering learning process was made by five experts from a renowned educational institute with expertise in computer, information and communication technology for education, and educational technology. The results are described in the following paragraphs.

1. The results of suitability evaluation on the design of instructional activities in the web-based learning system, as summarized in Table 5. 
Table 5. Results of suitability evaluation on the design of instructional activities of Imagineering learning process

\begin{tabular}{|c|c|c|c|}
\hline \multirow{2}{*}{ Evaluated contents } & \multicolumn{2}{|c|}{ Evaluation outcome } & \multirow{2}{*}{ Suitability level } \\
\hline & $\overline{\mathrm{x}}$ & S.D. & \\
\hline $\begin{array}{l}\text { 1. Creativity in the design of instructional activities } \\
\text { by means of Imagineering learning process }\end{array}$ & 4.20 & 0.45 & high \\
\hline $\begin{array}{l}\text { 2. The design of instructional activities is compliant } \\
\text { with the six steps of Imagineering learning process }\end{array}$ & 4.00 & 0.00 & high \\
\hline $\begin{array}{l}\text { 3. The completion of instructional activities is compli- } \\
\text { ant with the Imagineering learning process }\end{array}$ & 4.00 & 0.00 & high \\
\hline $\begin{array}{l}\text { 4. The instructional activities developed by means } \\
\text { of Imagineering learning process can enhance the } \\
\text { creative construction of multimedia skills and } \\
\text { cooperative learning skills }\end{array}$ & 4.60 & 0.55 & highest \\
\hline $\begin{array}{l}\text { 5. The instructional activities developed by means of } \\
\text { Imagineering learning process are flexible and can } \\
\text { be applied to other relevant researches }\end{array}$ & 4.40 & 0.55 & high \\
\hline $\begin{array}{l}\text { 6. The learning tools in the instructional activities } \\
\text { by means of Imagineering learning process can } \\
\text { enhance the creative construction of multimedia } \\
\text { skills and cooperative learning skills }\end{array}$ & 4.60 & 0.55 & highest \\
\hline $\begin{array}{l}\text { 7. There are projects that promote the development } \\
\text { of creative construction of multimedia skills and } \\
\text { cooperative learning skills }\end{array}$ & 5.00 & 0.00 & highest \\
\hline $\begin{array}{l}\text { 8. The design of instructional activities by means of } \\
\text { Imagineering learning process can enhance coopera- } \\
\text { tive learning skills among the learners }\end{array}$ & 4.80 & 0.45 & highest \\
\hline $\begin{array}{l}\text { 9. Efficiency of application of instructional activities by } \\
\text { means of Imagineering learning process }\end{array}$ & 4.20 & 0.45 & high \\
\hline Overall suitability & 4.42 & 0.50 & high \\
\hline
\end{tabular}

Table 5 shows the suitability evaluation on the design of instructional activities in the web-based learning system and Imagineering learning process under nine evaluation frameworks. Overall suitability was rated at the high level $(\overline{\mathrm{x}}=4.42, \mathrm{~S} . \mathrm{D} .=0.50)$.

2. The results of evaluation on the practical use of web-based learning system, as summarized in Table 6. 
Table 6. Results of suitability evaluation on the practical use of the web-based learning system

\begin{tabular}{|l|c|c|l|}
\hline \multirow{2}{*}{ Evaluated contents } & \multicolumn{2}{|c|}{ Evaluation outcome } & \multirow{2}{*}{ Suitability level } \\
\cline { 2 - 3 } & $\overline{\mathrm{x}}$ & \multicolumn{1}{|c|}{ S.D. } & \\
\hline $\begin{array}{l}\text { 1. The web-based learning system can enhance the } \\
\text { creative construction of multimedia skills and } \\
\text { cooperative learning skills of the learners by means } \\
\text { of Imagineering learning process }\end{array}$ & 4.40 & 0.55 & high \\
\cline { 1 - 3 } $\begin{array}{l}\text { 2. The web-based learning system can enhance the } \\
\text { creative construction of multimedia skills and } \\
\text { cooperative learning skills of the learners by means } \\
\text { of project-based learning }\end{array}$ & 4.80 & 0.45 & highest \\
\hline $\begin{array}{l}\text { 3. The web-based learning system can enhance the } \\
\text { learning achievement of the learners by means of } \\
\text { Imagineering learning process }\end{array}$ & 4.40 & 0.55 & high \\
\hline $\begin{array}{l}\text { 4. The web-based learning system can enhance } \\
\text { cooperative learning skills among the learners by } \\
\text { means of Imagineering learning process }\end{array}$ & 4.00 & 0.00 & high \\
\hline $\begin{array}{l}\text { 5. The web-based learning system can possibly } \\
\text { applied in the practical use }\end{array}$ & 4.20 & 0.45 & high \\
\hline \multicolumn{1}{|c|}{ Overall suitability } & $\mathbf{4 . 3 6}$ & $\mathbf{0 . 4 9}$ & high \\
\hline
\end{tabular}

Table 6 shows the suitability evaluation on the practical use of the web-based learning system under five evaluation frameworks. Overall suitability was rated at the high level $(\overline{\mathrm{x}}=4.36$, S.D. $=0.49)$.

\section{Conclusion}

The researchers designed and developed a web-based learning system using project-based learning and Imagineering as a tool to support learning in students. This further encourages their interactions and cooperative working style, which is useful in enhancing the creative construction of multimedia skills and cooperative learning skills. The development was made under the principles that support project-based learning and the Imagineering learning process. The conclusion can be made as follows:

1. The system architecture consists of three main elements, i.e. (1.1) Stakeholders; (1.2) System Components, i.e. Learning process, Activity, System Element, and Communication Tools; and (1.3) Database.

2. A web-based learning system using project-based learning and Imagineering can be divided into two sections: (1) Student system, which demonstrates course descriptions, lesson contents, and a student management system, including a webboard. This section consisted of six submenus: course description menu; lesson menu; webboard menu; student management menu; sitemap menu; and contact menu. (2) A lecturer system and administrator system was the system used for the purpose of learning administration and management made for the students. This system con- 
sisted of seven submenus: lesson configuration menu; student monitoring menu; study result report; lecturer management menu; news and announcement management menu; webboard menu; and sitemap menu.

3 . The results an evaluation of the quality of the contents and the quality of the system design under six evaluation frameworks showed that the overall quality of the web-based learning system was rated at a high level $(\overline{\mathrm{x}}=4.49$, S.D. $=0.54)$.

4. The efficiency evaluation under five evaluation frameworks has shown that the developed web-based learning system was rated at the highest level (overall components) $(\overline{\mathrm{X}}=4.55$, S.D. $=0.58)$.

5. The suitability evaluation on the design of instructional activities in the web-based learning system and Imagineering learning process was rated at the high level (overall components $)(\overline{\mathrm{x}}=4.42$, S.D. $=0.50)$.

6 . The suitability evaluation on the practical use of web-based learning system was rated at the high level (overall components) $(\overline{\mathrm{X}}=4.36$, S.D. $=0.49)$.

\section{Discussion}

The result of the development of the web-based learning system using projectbased learning and Imagineering, has shown that all five experts evaluated the overall system content and design quality at the high level, and evaluated the overall efficiency of the developed learning system at the highest level. This reflected that the design of the web-based learning system was in line with the principle and theories of system design [18], and the principle of e-learning design for learning and training [19]. This principle stated that e-learning design should consist of four components: Learning Management System (LMS), Content Management System (CMS), Test Management System (TMS) and Delivery Management System (DMS). These components can effectively enhance the development of a learning system and support learning in students. Researchers further tested the system using Robert, Alan and Barbara [17] Blackbox testing technique to test system efficiency, thus, resulting in the good performance of the developed system. This is consistent with Noppadon and Wannapiroon [20] findings that the ubiquitous learning using problem-based to enhance problem-solving skills and context learning, which used a learning system design that was in line with the four-system design could be implemented to enhance system performance. This is also consistent with Laisema and Wannapiroon [21] findings that the pilot performance testing using Blackbox testing, which consisted of five working systems: system capability, functionality, usability, security, and performance, can be used to test the developed system. Furthermore; a web designed by using the ADDIE Model [22], a systematic design, can also facilitate the quality of the website. 


\section{Acknowledgment}

The research was funded by the College of Industrial Technology, King Mongkut's University of Technology North Bangkok (Grant No. Res-CIT0301/2016). We gratefully acknowledge support from the Faculty of Technical Education, Research Centre for Vocational Education Technology, Institute Research of Science and Technology, at King Mongkut's University of Technology North Bangkok (KMUTNB).

\section{References}

[1] Rodmunkong, T., Wannapiroon, P. \& Nilsook, P. (2015). "The architecture of Information Management System through cloud computing according to Thai Qualifications Framework for Higher Education". 2015 IEEE International Conference on Teaching, Assessment, and Learning for Engineering (TALE), 10-12 December 2015, United International College, Zhuhai, China; pp.181-188.

[2] Nilsook, P. and Wannapiroon, P. (2014). "International Distance Consulting via Web Conferencing". International Journal of Emerging Technologies in Learning. Vol 9, No 4 (2014) ; pp. 60-64. http://dx.doi.org/10.3991/ijet.v9i4.3736

[3] Techakosit, S and Nilsook, P. (2016). "The Learning Process of Scientific Imagineering through AR in Order to Enhance STEM Literacy". International Journal of Emerging Technologies in Learning. Vol 11, No 7; 2016 ; pp. 57-63. http://dx.doi.org/10.3991/ijet.v11i07.5357

[4] Nilsook, P., Utakrit, N., and Clayden, J. (2014). "Imagineering in Education: A Framework to Enhance Students' Learning Performance and Creativity in Thinking". Educational Technology. January-Febuary 2014, Vol. 54 Issue 1; pp.14-20.

[5] Johnson, D. \& Johnson, R. (1987). Learning together and alone (2nd ed). Englewood Cliffs. NJ : Prentice Hall.

[6] Johnson, D. \& Johnson, R. (2003). Joining together : group theory and group skills. Boston : Allyn and Bacon.

[7] Nada Aldoobie. (2015). “ADDIE Model”. American International Journal of Contemporary Research. 5 (6) : 68-72. [online]. Retrieved September 11, 2016. from: http://www.aijcrnet.com/journals/Vol 5 No 6 December 2015/10.pdf

[8] Brahmawong, C. (1985). "Unit 12: Instructional System Management”. Textbook on Teaching Methodology Vol 8-15. Nonthaburi. Sukhothai Thammathirat Open University.

[9] Khemmani, T. (2010). Science of Teaching: Knowledge of Efficient Learning Process Management. Edition 13. Bangkok : Chulalongkorn University Press.

[10] Utranan, S. (1982). Systematic Instructional Management. Bangkok : Chulalongkorn University.

[11] Hall, R.H., Watkins, S.E. \& Eller, V.M. A Model of Web Based Design for Learning. [online] 2003, [cited 2013 July 17], Available from : URL : http://lite.mst.edu/media/research/ctel/documents/handbook 2003 hall.pdf

[12] Toporski, N. \& Foley, T, "Design principles for online instruction : A new kind of classroom." Journal of Distance Education. Vol. 5, No. 1 January 2004.

[13] Dabbagh, N, Pedagogical model for E-Learning : A Theory-Based Design Framework. International Journal of Technology in Teaching and Learning. Vol. 1, No. 1 (2005); pp. $25-44$. 
[14] Jansukwong, N. (2008). Research and Development of Project Activity Plans Applying Creative Problem-Solving Process to Develop Creative Thinking Teamwork Skills, and Product Quality of Elementary School Student. Degree of Master of Education Program in Educational Research. Department of Educational Research and Psychology. Faculty of Education Chulalongkorn University.

[15] Wongsuwan, S. (1999). Learning in the 21st century: Learning in which learners create knowledge by their own. Bangkok : Department of Curriculum and Instruction Development.

[16] Wright, A. (2008). The Imagineering Field Guide to Disneyland. Disney : Editions.

[17] Robert, Alan \& Barbara. (2013). Systems Analysis and Design (fifth editon). New Jersey : John Wiley\&Sons, Inc.

[18] Saraubon, K., Nilsook, P. \& Wannapiroon, P. (2016). "System Design of Mobile Augmented Book". International Journal of Interactive Mobile Technologies. Vol 10, No 1 ; pp. 52-59. http://dx.doi.org/10.3991/ ijim.v10i1.5276

[19] Nilsook, P., Armstrong, L., Taechatanaset, P., and Ranjeet, T. (2014). "Web-based training in e-Agriculture for Agricultural College". Proceedings of the 9th Conference of the Asian Federation for Information Technology in Agriculture. Perth, Western Australia, 29 September to 2 October 2014.

[20] Noppadon, P. \& Wannapiroon, P. (2013). "Design of Problem-based with Scaffolding Learning Activities in Ubiquitous Learning Environment to Develop Problem-solving Skills". 5th World Conference on Educational Sciences - WCES 2013. http://dx.doi.org/10.1016/j.sbspro.2014.01.1028.

[21] Laisema, S \& Wannapiroon, P. (2013). "Design of Collaborative Learning with Creative Problem-solving Process Learning Activities in a Ubiquitous Learning Environment to Develop Creative Thinking Skills". 5th World Conference on Educational Sciences - WCES 2013. http://dx.doi.org/10.1016/j.sbspro.2014.01.867.

[22] Jitsupa, J., Siriprichayakorn, R. \& Nilsook, P. (2015). "A Comparison of Academic Achievement in the English Subject, of Suan Dusit Rajabhat University Students Majoring in Early Childhood Education Who Developed Electronic Storybooks in English for Young Children Using the ADDIE model". ARTS-LC National Conference on Language Education and Communication. National Institute of Development Administration, September 3-4, 2015 ; pp.252-262. http://dx.doi.org/10.13140/RG.2.1.4045.1607

\section{Authors}

Pinanta Chatwattana is a $\mathrm{PhD}$ at the College of Industial Technology, King Mongkut's University of Technology North Bangkok (KMUTNB), Bangkok, Thailand, 10800. (e-mail: pinanta.c@cit.kmutnb.ac.th).

Prachyanun Nilsook is an associate professor at the Faculty of Technical Education, King Mongkut's University of Technology North Bangkok (KMUTNB), Bangkok, Thailand, 10800. He is a member of Professional Societies in the Association for Educational Technology of Thailand (AETT). (e-mail: prachyanun@hotmail.com). 